\title{
UVODNIK
}

\section{MIGRACIJE IN VARNOST NA STARI CELINI}

Dve leti mineva od evropske migrantske krize. Jeseni 2015 je Evropo preplavil begunski val, kakršnega nismo pričakovali in si ga nismo znali predstavljati. Presenetil nas je v vseh pogledih. Sodobna tehnologija, ugledne ustanove in vodilni svetovni strokovnjaki z različnih področij niso predvideli tega, kar se je zgodilo. Evropski pravni red, človekove pravice, schengenski režim in ideje Zahoda, ki so se hitro razblinile, nam pa je ostala samo gola realnost.

Kje so begunci zdaj, koliko jih je in kako se počutijo? Kako je begunska kriza vplivala na nacionalnovarnostni sistem, na skupno evropsko obrambno in varnostno politiko? Mediji o tem dve leti pozneje le redko poročajo. Veliko pa se govori o terorističnih napadih po evropskih mestih, o izstopu Velike Britanije iz Evropske unije, o ameriškem predsedniku Donaldu Trumpu in korejskih raketah, ki burkajo Japonsko morje.

Samuel P. Huntington je pred leti napisal knjigo Spopad civilizacij. V Sloveniji je izšla leta 2005. Izhajal je iz predpostavke, da bosta glavna razloga za spopade narodov v prihodnosti njihova kulturna in religiozna identiteta. Napovedal je, da bo največjo grožnjo predstavljal ekstremni terorizem. Različne ideologije bodo zamenjali individualno usmerjeni posamezniki, ki jim ne bo več mar za skupno dobro, temveč bodo osredotočeni nase in svoje koristi. Odsotnost ideologij bo nadomestilo vračanje $\mathrm{k}$ starodavnim tradicijam. Odzivi na Huntingtonovo delo so bili zelo različni. Nekateri so bili navdušeni, drugi skeptični. Lahko pa ugotovimo, da se je njegova teorija, ki jo je prvič predstavil leta 1992, potrdila na primeru vojne, ki se je zgodila na Zahodnem Balkanu. Ko se je ideologija nekdanje Jugoslavije razblinila, so se narodi in narodnosti vrnili k svojim koreninam in zgodila se je vojna, ki je zahtevala veliko življenj. 
O dejstvu, da je Zahodni Balkan prelomnica različnih kultur, je pisal tudi Robert D. Kaplan v svojih delih. Najbolj znano med njimi je Balkanski duh, v katerem podrobno preučuje zgodovinsko in kulturno turbulenco $\mathrm{v}$ neposredni soseščini zibelke zahodne civilizacije, ki je bila zadnjih več kot dva tisoč let gonilo razvoja Zahoda.

Zato nas v tokratni številki Sodobnih vojaških izzivov zanima, kaj je novega na stari celini, s poudarkom na varnostnem, obrambnem in vojaškem področju.

V članku Geostrateški premiki v sodobni Evropi Uroš Tovornik preučuje geostrateški pomen odnosov med Francijo, Nemčijo in Veliko Britanijo kot držav, ki so v preteklosti krojile usodo Evrope. Z odločitvijo Velike Britanije o izstopu iz Evropske unije se prej klasični geostrateški trikotnik lahko spremeni v druge odločilne geostrateške povezave, ki staro celino lahko zelo spremenijo.

József Kis-Benedek piše o posledicah dogajanja v severni Afriki in na Bližnjem vzhodu. Nekateri avtorji so se v bližnji preteklosti spraševali, ali bo po arabski pomladi nastopila arabska zima, sledila pa sta evropska migrantska kriza ter povečanje terorističnih napadov v Evropi. V članku Izzivi iraške, sirske in libijske krize za Evropsko unijo se avtor posveča vprašanju udeležbe borcev na kriznih območjih, ki prihajajo na pomoč iz Evrope.

Gospodarska obveščevalna dejavnost: neizogibna izbira je naslov članka, ki ga je napisal Laris Gaiser. V njem poudarja nujnost večje pozornosti, ki jo mora Slovenija nameniti temu področju, da bo zagotavljala večjo dobrobit svojim državljanom. Po letu 1991 je Slovenija dosegla veliko, toda sodobne varnostne smernice določajo, da je poleg klasičnih nalog na obveščevalno-varnostnem področju pomembna tudi gospodarska obveščevalna dejavnost. Kako je s tem v Sloveniji in kaj bi še morali storiti?

Slovenska vojska že nekaj let sodeluje $\mathrm{v}$ mednarodni operaciji in na misiji $\mathrm{v}$ Bosni in Hercegovini. Tam ni edina, saj poleg nje za red in mir skrbijo še številne druge države članice Evropske unije. Kako dolgo bo še tako in kako uspešne so mednarodne varnostne sile na tem območju? $\mathrm{Na}$ to in nekatera druga vprašanja poskušajo odgovoriti avtorji Ivana Boštjančič Pulko, Johanna Suhonen in Kari Sainio v članku Ocenjevanje načrtovanja in izvajanja misij ter operacij EU: študija primera EUFOR Althea $v$ Bosni in Hercegovini.

Kibernetika, kibernetski prostor in kibernetski napadi so splošno znani pojmi, o katerih zadnje čase veliko slišimo in beremo. Ali te pojme res dobro poznamo? Kako je s pravnimi podlagami na nacionalni ravni in kako je to področje urejeno $\mathrm{v}$ mednarodnem okolju? To je izziv, na katerega je treba najti strateške in povsem konkretne odgovore. Enega izmed mogočih lahko najdemo v članku Zakonitost nizkointenzivnih kibernetskih operacij po mednarodnem pravu avtorice Pike Šarf. 
Vojaško letalstvo je sestavni del sodobnih oboroženih sil. Slovensko je razmeroma mlado in je v svoji kratki zgodovini doživelo več razvojnih faz tako na področju letalske stroke kot tudi v organizacijskem vojaškem smislu. Kakovostno sodelovanje slovenskih vojaških pilotov $\mathrm{v}$ mednarodnih operacijah in na misijah ter mednarodnih vojaških vajah priča o tem, da smo na pravi poti. Toda kako naprej? Avtor Mitja Lipovšek se v članku Slovensko vojaško letalstvo danes in čez 20 let sklicuje na misel, da je zgodovina razprava preteklosti s sedanjostjo za prihodnost.

Obilo zanimivega branja vam želimo in vas vabimo k sodelovanju tudi kot avtorje člankov. 